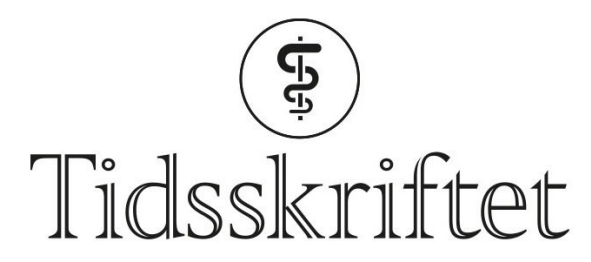

DEN NORSKE LEGEFORENING

\title{
Resistens i gamle bakteriekulturer
}

FRA ANDRE TIDSSKRIFTER

RUTH HALSNE

Tidsskriftet

Nye studier av en 102 år gammel bakteriekultur avslører hvordan en mikrobe fremkalte sykdom.

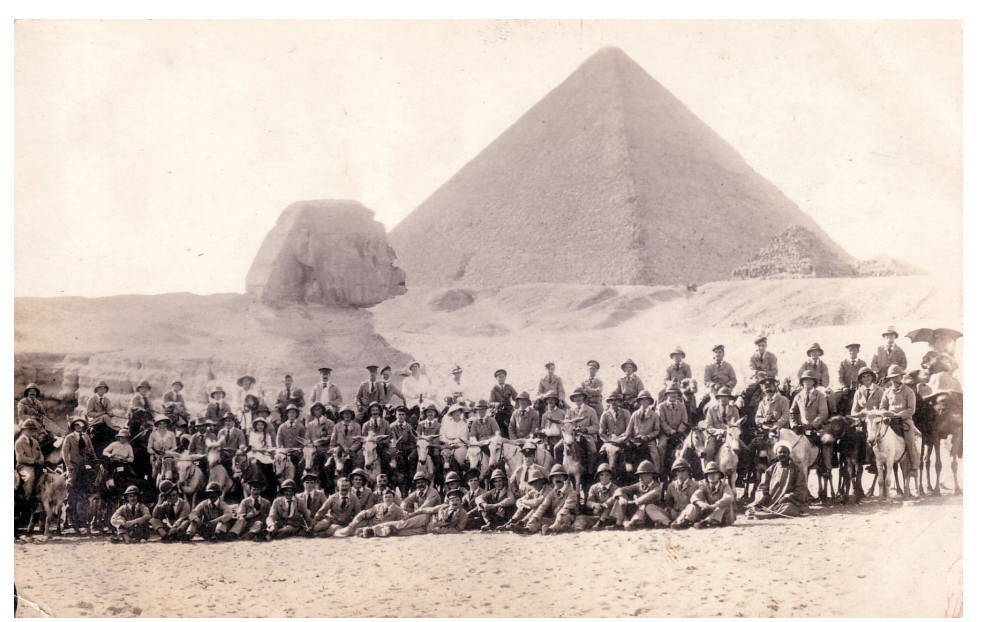

Den syke soldaten var stasjonert $i$ Egypt. Tittelen på bildet foran sfinksen $i$ Giza lyder «63 sårede og syke soldater på kameler og esler», mest sannsynlig fra Mena House Hotel som ble brukt som sykehus under første verdenskrig. Bildet er en del av nettutstillingen "Views of an Antique Land: Imaging of Egypt and Palestine during the First World War». Eier av foto: Paul T. Nicholson.

I 1916, under første verdenskrig, ble en britisk soldat innlagt på sykehus med diaré. En kolerapandemi raste, men med få rapporterte tilfeller i de britiske styrkene. En bakteriekultur med Vibrio cholerae (NTCT3o) ble isolert fra soldaten og bevart. Det er nylig utført og publisert en genomisk og fenotypisk karakterisering av denne bakteriekulturen $(1)$.

Gensekvensering viste at mikroben manglet det klassiske toksinet som forårsaker koleradiaré. Mikroben hadde en nålliknende struktur på overflaten som likner strukturen til andre bakterier som brukes for å injisere proteiner direkte inn i vertsceller. Denne strukturen antas å ha forårsaket soldatens diaré. I tillegg fant man gensekvensen for betalaktamaseresistens. Penicillinresistens ble bekreftet ved å klone genet inn i Escherichia coli og teste sensitiviteten mot penicillin.

- Det er spennende at resistensgener blir funnet i gamle bakteriekulturer, sier Pål Jarle Johnsen, som er professor og forskningsgruppeleder ved Institutt for farmasi ved UiT Norges arktiske universitet. Integroner er store klaser med funksjonelle gener som 
uttrykkes fra en felles promoter. Bakteriestammen i denne studien tilhører Vibrio-familien, der det ofte er enorme integroner med opptil flere promotorer. Det er kjent at betalaktamaser har eksistert i flere millioner år og at dette sannsynligvis er en evolusjonær respons på betalaktamproduserende mikroorganismer i ulike miljøer, sier Johnsen.

\section{LITTERATUR:}

1. Dorman MJ, Kane L, Domman D et al. The history, genome and biology of NCTC3o: a non-pandemic Vibrio cholerae isolate from World War One. Proc Biol Sci 2019; 286: 20182025. [PubMed][CrossRef]

Publisert: 26. mars 2020. Tidsskr Nor Legeforen. DOI:10.4045/tidsskr.20.0074

(C) Tidsskrift for Den norske legeforening 2020. Lastet ned fra tidsskriftet.no 